\title{
The heart of bureaucratic power: Explaining international bureaucracies' expert authority
}

\author{
Andrea Liese* (D), Jana Herold (D), Hauke Feil (D) and Per-Olof Busch (D) \\ University of Potsdam Faculty of Economic and Social Science, Potsdam, Brandenburg, Germany \\ ${ }^{\star}$ Corresponding author. Email: aliese@uni-potsdam.de
}

(Received 5 December 2019; revised 2 January 2021; accepted 4 January 2021; first published online 22 February 2021)

\begin{abstract}
Expert authority is regarded as the heart of international bureaucracies' power. To measure whether international bureaucracies' expert authority is indeed recognised and deferred to, we draw on novel data from a survey of a key audience: officials in the policy units of national ministries in 121 countries. Respondents were asked to what extent they recognised the expert authority of nine international bureaucracies in various thematic areas of agricultural and financial policy. The results show wide variance. To explain this variation, we test well-established assumptions on the sources of de facto expert authority. Specifically, we look at ministry officials' perceptions of these sources and, thus, focus on a less-studied aspect of the authority relationship. We examine the role of international bureaucracies' perceived impartiality, objectivity, global impact, and the role of knowledge asymmetries. Contrary to common assumptions, we find that de facto expert authority does not rest on impartiality perceptions, and that perceived objectivity plays the smallest role of all factors considered. We find some indications that knowledge asymmetries are associated with more expert authority. Still, and robust to various alternative specifications, the perception that international bureaucracies are effectively addressing global challenges is the most important factor.
\end{abstract}

Keywords: Expert Authority; International Bureaucracies; International Organisations; Neutrality; Performance; Survey

\section{Introduction}

The expert authority of international bureaucracies ${ }^{1}$ - an authority ascribed to them as providers of expertise-based recommendations - has been widely discussed in the literature on international organisations (IOs). ${ }^{2}$ Scholars argue that this authority constitutes the heart of bureaucratic power' of IOs and enables them to influence both international and national policy. ${ }^{3}$ However, expert authority also rests on a social relationship between an authority holder and a

\footnotetext{
${ }^{1}$ The term international bureaucracy refers to IOs' administrative bodies, which are staffed by international civil servants in so-called secretariats and which can be distinguished from IOs' governing and dispute settlement bodies. See, for example, Steffen Bauer and Silke Weinlich, 'International bureaucracies: Organizing world politics', in Bob Reinalda (ed.), The Ashgate Research Companion to Non-State Actors (Burlington, VT: Ashgate, 2011), pp. 251-62; Dominique de Wit, Abby Lindsay Ostovar, Steffen Bauer, and Sikina Jinnah, 'International bureaucracy', in Frank Biermann and Rakhyun Kim (eds), Architectures of Earth System Governance: Institutional Complexity and Structural Transformation (Cambridge: Cambridge University Press, 2020), pp. 57-74.

${ }^{2}$ Michael Barnett and Martha Finnemore, Rules for the World: International Organizations in Global Politics (Ithaca, NY: Cornell University Press, 2004), pp. 24-5; Matthias Ecker-Ehrhardt, “"But the UN said so ...” International organisations as discursive authorities', Global Society, 26:4 (2012), pp. 51-71; Michael Zürn, A Theory of Global Governance. Authority, Legitimacy, and Contestation (Oxford: Oxford University Press, 2018).

${ }^{3}$ Barnett and Finnemore, Rules for the World, p. 29.

(C) The Author(s) 2021. Published by Cambridge University Press on behalf of the British International Studies Association. This is an Open Access article, distributed under the terms of the Creative Commons Attribution licence (http://creativecommons.org/licenses/by/4.0/), which permits unrestricted re-use, distribution, and reproduction in any medium, provided the original work is properly cited.
} 
subordinate. In the case of international bureaucracies, such relationships are characterised by substantial yet insufficiently understood variation in the authority ascribed to a bureaucracy by its audience, that is, by the addressees of its advice. We therefore ask: What explains the variation in the expert authority of international bureaucracies among national addressees?

This question is relevant in light of strong indications that variations exist that cannot be explained based on formal competences alone. ${ }^{4}$ While recent research has made impressive inroads into the study of international authority, including its variation over time and among IOs, ${ }^{5}$ much of this research has focused on the formal delegation of tasks and responsibilities, which we refer to as 'de jure expert authority'. Almost all IO bureaucracies have gained substantial mandates to provide expertise in recent years, including the collection of data, the generation of knowledge, and the provision of policy advice. Yet while the act of delegation includes a promise to defer to an organisation in the future, for instance by acting upon its recommendations and requests, addressees may eventually not do so. ${ }^{6}$ Whereas the competencies associated with de jure expert authority are not necessarily always recognised and deferred to in practice, in the case of 'de facto authority', they are.

This discrepancy has largely not been addressed in the research because many scholars have focused on inter-IO comparisons and on the global influence of international bureaucracies. ${ }^{7}$ However, case study research - for instance, studies on the expert authority of specific international bureaucracies, ${ }^{8}$ treaty secretariats, ${ }^{9}$ and peer review mechanisms in $\mathrm{IOs}^{10}$ - has produced a more nuanced picture of the ways in which expert authority can increase or decrease due to the elements inherent in the relationship between international bureaucracies and their addressees. This research has found that authority depends on the 'specific social settings', ${ }^{11}$ that it 'is not

\footnotetext{
${ }^{4}$ Frank Biermann and Bernd Siebenhüner, 'The role and relevance of international bureaucracies: Setting the stage', in Frank Biermann and Bernd Siebenhüner (eds), Managers of Global Change The Influence of International Environmental Bureaucracies (Cambridge, MA and London: The MIT Press, 2009), pp. 1-14 (p. 10); Per-Olof Busch, Mirko Heinzel, Mathies Kempken, and Andrea Liese, 'Mind the gap? Comparing de facto and de jure expert authority of international public administrations in financial and agricultural policy', Journal of Comparative Policy Analysis: Research and Practice, First View (2020).

${ }^{5}$ Liesbet Hooghe, Gary Marks, Tobias Lenz, Jeanine Bezuijen, Besir Ceka, and Svet Derderyan, Measuring International Authority: A Postfunctionalist Theory of Governance (Oxford: Oxford University Press, 2017); Michael Zürn, Alexandros Tokhi, and Martin Binder, 'The International Authority Database (IAD)', unpublished manuscript (2020).

${ }^{6}$ See Karen J. Alter, Laurence R. Helfer, and Mikael Rask Madsen, 'How context shapes the authority of international courts', Law and Contemporary Problems, 79:1 (2016), pp. 1-36.

${ }^{7}$ Hooghe et al., Measuring International Authority; Frank Biermann and Bernd Siebenhüner, 'The influence of international bureaucracies in world politics: Findings from the MANUS research program', in Biermann and Siebenhüner (eds), Managers of Global Change, pp. 319-49.

${ }^{8}$ Barnett and Finnemore, Rules for the World; Colin McInnes, 'WHO's next? Changing authority in global health governance after Ebola', International Affairs, 91:6 (2015), pp. 1299-316; Ole Jacob Sending and Jon Harald Sande Lie, 'The limits of global authority: World Bank benchmarks in Ethiopia and Malawi', Review of International Studies, 41:5 (2015), pp. 9931010; Silke Weinlich, '(Re)generating peacekeeping authority: The Brahimi process', Journal of Intervention and Statebuilding, 6:3 (2012), pp. 257-77; Lars Bo Kaspersen and Maria Svaneborg, 'The OECD as a scientific authority? The OECD's influence on Danish welfare policies', in Klaus Armingeon and Michelle Beyeler (eds), The OECD and European Welfare States (Cheltenham: Edward Elgar Publishing, 2004), pp. 32-43.

${ }^{9}$ Steffen Bauer, 'Does bureaucracy really matter? The authority of intergovernmental treaty secretariats in global environmental politics', Global Environmental Politics, 6:1 (2006), pp. 23-49; Sikina Jinnah, 'Overlap management in the World Trade Organization: Secretariat influence on trade-environment politics', Global Environmental Politics, 10:2 (2010), pp. 54-79; Helge Joergens, Nina Kolleck, and Barbara Saerbeck, 'Exploring the hidden influence of international treaty secretariats: Using social network analysis to analyse the Twitter debate on the "Lima Work Programme on Gender", Journal of European Public Policy, 23:7 (2016), pp. 979-98.

${ }^{10}$ Valentina Carraro and Hortense Jongen, 'Leaving the doors open or keeping them closed? The impact of transparency on the authority of peer reviews in international organizations', Global Governance, 24:4 (2018), pp. 615-35; Hortense Jongen, 'The authority of peer reviews among states in the global governance of corruption', Review of International Political Economy, 25:6 (2018), pp. 909-35.

${ }^{11}$ Ole Jacob Sending, The Politics of Expertise: Competing for Authority in Global Governance (Ann Arbor: University of Michigan Press, 2015), p. 21.
} 
a fixed quality any actor may possess', ${ }^{12}$ 'does not spring magically from some ideal-typical "source" of authority', ${ }^{13}$ and that it may vary, not only among international bureaucracies and over time, but also between the international bureaucracy and its various subordinates. Furthermore, these previous assessments and explanations of authority have shown that authority, while likely delegated, draws on other sources as well, including perceptions of international bureaucracies as impactful and objective. ${ }^{14}$ By providing a systematic analysis of large-N variations in the expert authority ascribed to international bureaucracies by a key audience, we add to these debates.

In addition, our analysis contributes to the burgeoning literature on the power of international bureaucracies. ${ }^{15}$ This literature has increasingly focused on the structural conditions under which international bureaucracies become influential. For instance, regime complexity creates a demand for overlap management and offers a vacant slot in global governance that international bureaucracies fill. ${ }^{16}$ Technical and scientific uncertainty increase state demand for international bureaucracies' expertise, while low issue salience increases the autonomy of international bureaucrats, ${ }^{17}$ another important source of international bureaucracies' influence. ${ }^{18}$ Much of this research has focused on international bureaucracies' influence at the global level, for instance, their influence on the institutional design of newly created $\mathrm{IOs}^{19}$ or on the incorporation of new issues into regimes. ${ }^{20}$ We add to this research by, inter alia, shifting the focus from their role as 'managers of global change ${ }^{, 21}$ to their role on the national level.

We used novel data from a global survey of policy units in national ministries in 121 countries to assess the scope and variation of de facto expert authority. This survey captures the extent to which international bureaucracies possess de facto expert authority among this important group of addressees. We selected nine international bureaucracies as potential authority holders and asked the policy officials to what extent they recognised these bureaucracies' expert authority in eight thematic areas: four in the policy field of agriculture and four in the policy field of finance. The sample is representative of all UN regions and all World Bank income groups. We achieved a response rate of 38 per cent. Our data reveal that de facto expert authority varies not only across international bureaucracies but also across thematic areas and addressees.

To explain the variation in de facto expert authority, we tested the most prominent assumptions in the literature about the sources of de facto expert authority. Specifically, we focused on perceptions of international bureaucracies to better understand how the relationship between an international bureaucracy and its addressees systematically shapes the expert authority the international bureaucracy holds over them. We examined the role of international bureaucracies' impartiality, objectivity, and impact, as perceived by their national addressees. We also studied the role of knowledge asymmetries between national addressees and international bureaucracies, as these make it more likely that addressees will recognise them as experts and defer to their

\footnotetext{
${ }^{12}$ Weinlich, '(Re)generating peacekeeping authority', p. 260.

${ }^{13}$ Sending and Lie, 'The limits of global authority', p. 996.

${ }^{14}$ See, for example, Jongen, 'The authority of peer reviews', pp. 929-30; Sending, The Politics of Expertise, p. 16; and the overview by de Wit et al., 'International bureaucracy', pp. 65, 68.

${ }^{15}$ Steffen Eckhard and Jörn Ege, 'International bureaucracies and their influence on policy-making: A review of empirical evidence', Journal of European Public Policy, 23:7 (2016), pp. 960-78.

${ }^{16}$ Sikina Jinnah, Post-Treaty Politics: Secretariat Influence in Global Environmental Governance (Cambridge, MA and London, England: MIT Press, 2014).

${ }^{17}$ Tana Johnson, 'Looking beyond States: Openings for international bureaucrats to enter the institutional design process', The Review of International Organizations, 8:4 (2013), pp. 499-519.

${ }^{18}$ Michael Bauer and Jörn Ege, 'Bureaucratic autonomy of international organizations' secretariats', Journal of European Public Policy, 23:7 (2016), pp. 1019-37.

${ }^{19}$ Tana Johnson and Johannes Urpelainen, 'International bureaucrats and the formation of intergovernmental organizations: Institutional design discretion sweetens the pot', International Organization, 68:1 (2014), pp. 177-209.

${ }^{20}$ Joergens et al., 'Exploring the hidden influence'.

${ }^{21}$ Biermann and Siebenhüner (eds), Managers of Global Change.
} 
authority. In doing so, we compare these factors with alternative sources of influence, such as coercion, third-party pressure, and national interest.

Four findings stand out. First, the perception of international bureaucracies' global impact, that is, their perceived contribution to effectively addressing global challenges, has the greatest effect on their de facto expert authority. Second, we find that perceptions of objectivity play the smallest role of all the determinants considered. Third, we find that varying impartiality perceptions are not associated with varying degrees of expert authority. This partially challenges well-established arguments in some strands of the literature on expert authority, where objectivity and impartiality are seen as central. Finally, we find some indications that knowledge asymmetries might play a role in expert authority.

The article begins by conceptualising de facto expert authority and briefly mapping its variation. A description of our data shows the variation that we seek to explain. Second, we specify established assumptions under which de facto expert authority becomes likely. Third, we describe the methods and models we use, before turning, fourth, to a series of tests and analyses. Finally, we outline implications for the further study of international authority and the influence of international bureaucracies.

\section{International bureaucracies' expert authority}

Our article focuses on the concept of de facto expert authority. In the following, we briefly discuss key characteristics of expert authority before elaborating on the specific form of de facto authority. Then we turn to the variation in the expert authority international bureaucracies hold over national addressees.

\section{What is expert authority?}

Expert authority (or epistemic authority) is a specific type of authority. It denotes the recognition of experts' competency to make (and communicate) assessments, judgements, and recommendations based on their knowledge, ${ }^{22}$ which enables them to 'structure the behavior of others'. ${ }^{23}$ While expert authority can be distinguished from other types of authority, such as political authority, ${ }^{24}$ it shares the essential characteristics of a broader and more general concept of authority. In recent years, the concept has proven to be useful for theorising hierarchical relationships among various actors that participate in global governance. ${ }^{25}$ It is generally defined as a social relationship and a distinct form of power. First, authority rests on a social and hierarchical relationship between at least two actors. In this relationship, the superior actor claims or exercises authority by ordering or requesting certain actions, while the subordinate actor recognises this privilege and voluntarily defers to the respective commands or requests, that is, does what an authority holder asks. ${ }^{26}$ The relationship is, thus, recognised and entails deference. Second,

\footnotetext{
${ }^{22}$ Barnett and Finnemore, Rules for the World, pp. 24-5; Busch et al., 'Mind the gap?', pp. 3-5.

${ }^{23}$ Michael Zürn, 'From constitutional rule to loosely coupled spheres of liquid authority: A reflexive approach', International Theory, 9:2 (2017), pp. 261-85 (p. 277).

${ }^{24}$ Political authority is understood as the recognition that an IO can make and enforce collectively binding decisions. See, for example, David A. Lake, 'Rightful rules: Authority, order, and the foundations of global governance', International Studies Quarterly, 54:3 (2010), pp. 587-613.

${ }^{25}$ See, for example, Alter et al., 'How context shapes'; Carraro and Jongen, 'Leaving the doors open'; Hylke Dijkstra, 'Collusion in international organizations: How states benefit from the authority of secretariats', Global Governance, 23:4 (2017), pp. 601-18; Jessica F. Green, Rethinking Private Authority: Agents and Entrepreneurs in Global Environmental Governance (Princeton, NJ: Princeton University Press, 2014); Hooghe et al., Measuring International Authority; Ian Hurd, 'Legitimacy and authority in international politics', International Organization, 53:2 (1999), pp. 379-408; Lake, 'Rightful rules'; Sending, The Politics of Expertise; Zürn, A Theory of Global Governance.

${ }^{26}$ Barnett and Finnemore, Rules for the World, pp. 29, 34; Richard B. Friedman, 'On the concept of authority in political philosophy', in Joseph Raz (ed.), Authority (New York: New York University Press, 1990), pp. 56-91 (pp. 63-8); Hooghe
} 
authority is regarded as a distinct form of power. ${ }^{27}$ Following Hannah Arendt, ${ }^{28}$ many scholars distinguish authority from other modes of social control, notably from 'both coercion by force and persuasion by arguments', which relate to other motives for deference. ${ }^{29}$ In the case of authority, deference should be based on trust in certain qualities of the actor that claims authority, for example, credibility. ${ }^{30}$

Recognition is key to the concept of authority in general as well as to its specific variants. Authority is recognised in two key ways. On the one hand, subordinate actors may place an actor 'in authority ${ }^{31}$ by approving rules that formally establish their subordination and by delegating tasks and powers to the authority holder. This variant is often called 'delegated authority ${ }^{32}$ or 'de jure authority'. ${ }^{33}$ It is typically preceded by an act of delegation and entails a promise to defer in the future. On the other hand, subordinate actors may make an actor 'an authority ${ }^{34}$ by recognising it through their behaviour, also referred to as 'de facto authority'. ${ }^{35}$ In this variant, authority can be ascribed irrespective of a formal act of authorisation. Subordinate actors then recognise a superior actor's privilege to request certain actions and do or at least consider doing what they are asked to do. Existing research on international authority has been strongly shaped by this distinction and the related means of measuring authority. Thus, the different forms of recognition also matter empirically. De jure authority of IOs has increased over time and varies widely among IOs. For example, the Organisation for Economic Co-operation and Development (OECD) has relatively low de jure authority, while the International Monetary Fund (IMF) scores relatively high. ${ }^{36}$ Yet, given that delegation means that a collective principal (a group of member states) conditionally grants authority to an agent (an IO or international bureaucracy), the mere act of delegation cannot tell us much about the varying degrees to which subordinates adhere to this decision and defer to the agent in practice.

Hence, we apply a concept of de facto expert authority. In doing so, we adhere to the view, outlined above, that authority is a social, not merely a contractual, relationship. This relationship is built on behavioural recognition and includes deference. We, therefore, examine whether a key audience considers international bureaucracies' policy recommendations because they regard them as experts.

\section{Variation in de facto expert authority}

Our data, which we describe below, show that the extent to which international bureaucracies hold de facto expert authority varies considerably across ministry officials, international bureaucracies, policy fields, and thematic areas. Figure 1 displays how responses of ministry officials are distributed across the response categories in a survey question on de facto expert authority of a sample of nine international bureaucracies (on an ascending scale from 1 to 7 ).

Figure 2 further highlights that expert authority varies across the actors recognising and deferring to the authority (see values) and across policy fields (see variations in shading of the boxes). We also find variation across thematic areas in the same policy field. For example, the IMF, OECD, and World Bank all have less expert authority in monetary policy than in other thematic

et al., Measuring International Authority, p. 14; Nico Krisch, 'Liquid authority in global governance', International Theory, 9:2 (2017), pp. 237-60 (p. 247); Sending, The Politics of Expertise, p. 5; Zürn, 'From constitutional rule', p. 266.

${ }^{27}$ Lake, 'Rightful rules', p. 592; Hooghe et al., Measuring International Authority, p. 14.

${ }^{28}$ Hannah Arendt, On Violence (Orlando, FL: Harcourt, Brace \& Company, 1970), p. 93.

${ }^{29}$ For a discussion in IO research, see Ecker-Ehrhardt, "'But the UN said so"', p. 457.

${ }^{30}$ Friedman, 'On the concept of authority in political philosophy', p. 80.

${ }^{31}$ Ibid., p. 77-9.

${ }^{32}$ Barnett and Finnemore, Rules for the World, pp. 22-3; Hooghe et al., Measuring International Authority, p. 23.

${ }^{33}$ Alter et al., 'How context shapes', p. 3; Green, Rethinking Private Authority, p. 7.

${ }^{34}$ Friedman, 'On the concept of authority in political philosophy', p. 60.

${ }^{35}$ Alter et al., 'How context shapes'; Green, Rethinking Private Authority, p. 7.

${ }^{36}$ Hooghe et al., Measuring International Authority. 


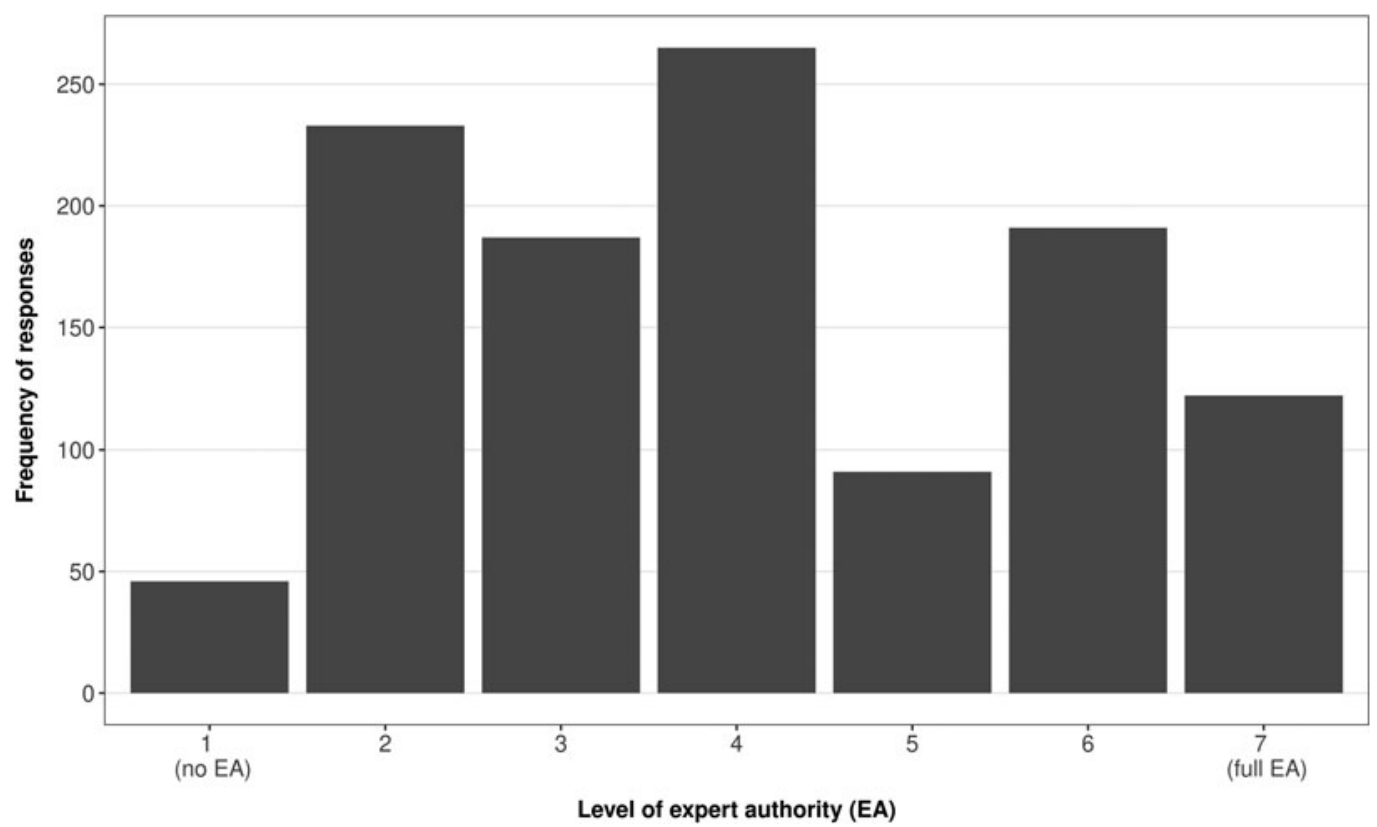

Figure 1. Absolute frequency of responses regarding the degree of expert authority. Source: Our survey (see research design below).

areas (see Figures A1, Appendix A; A2, Appendix C in the supplementary material). Three observations stand out. First, and not surprisingly, international bureaucracies vary in the level of expert authority ascribed to them: The IMF has, on average, the highest expert authority. Second, de facto authority varies across policy fields as domains of authority. In the policy field of agriculture, the variation among international bureaucracies is less pronounced than in finance. Looking at the OECD and World Bank individually, we observe that each international bureaucracy shows wide variation in expert authority across policy fields. Third, there is wide variation in the expert authority of the same international bureaucracy across ministry officials (as shown by the dots in Figure 2). Except for UNCTAD (in financial policy) and UN DESA, ministry officials' responses are spread among all possible response categories.

Our data on international bureaucracies' de facto expert authority confirms that authority appears 'in gradations ${ }^{37}$ and that the same bureaucracy may have authority in one setting but not in another. This variation corroborates the importance of studying authority as a social relationship between international bureaucracies as authority holders and their addressees as potential authority followers (here: policy units in national ministries). It is this relationship that we seek to explain.

\section{Explaining the variation in de facto expert authority: Theories and hypotheses}

While de jure authority is usually explained with reference to functionalist or rationalistinstitutionalist theories, de facto expert authority is often explained with reference to sources of authority within the international bureaucracy. The latter may be a result of the delegation of authority that occurs in the case of de jure authority, but the literature typically assumes that de facto authority rests on alternative attributes, such as expertise. ${ }^{38}$ Still, not every

\footnotetext{
${ }^{37}$ Krisch, 'Liquid authority', p. 243. See also Biermann and Siebenhüner, 'The influence of international bureaucracies', p. 321 .

${ }^{38}$ Barnett and Finnemore, Rules for the World, p. 24.
} 


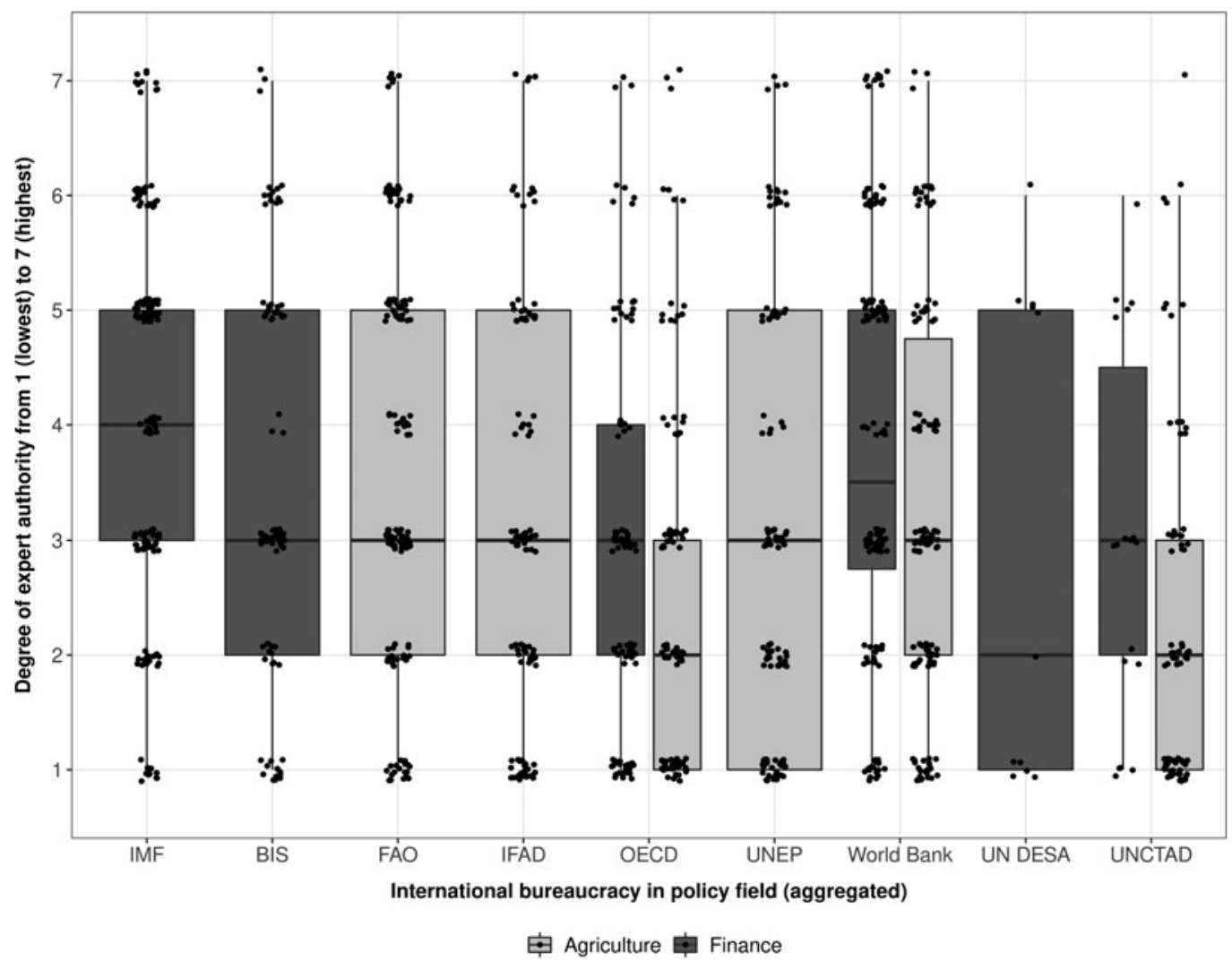

Figure 2. Expert authority: Boxplot by international bureaucracy.

Source: Our survey (see research design below). Data are grouped by international bureaucracy in the policy fields of agriculture and finance, respectively, and ordered according to an international bureaucracy's overall median level of expert authority.

international bureaucracy has these attributes or is recognised as having these attributes. Ole Jacob Sending, for example, argues that 'authority - as a relational phenomenon - cannot be determined by looking at the attributes of one actor'. ${ }^{39}$ And Michael Barnett and Martha Finnemore also emphasise that international bureaucracies 'must be seen to serve some valued and legitimate social purpose, and, further they must be seen to serve that purpose in an impartial and technocratic way' in order to become or stay 'authoritative, ergo powerful'. ${ }^{40}$ While many scholars acknowledge the relational character of authority, only few have examined how a key audience perceives what could count as a source of authority. ${ }^{41}$

Therefore, our explanations pay heed to the addressees of international bureaucracies' expert advice and are sensitive to their perceptions, assessments, and demands. In the following, we introduce the most established assumptions on the different sources of de facto expert authority and indicate how we operationalise them to bring in the views of those who are asked to recognise and defer to the expert authority of international bureaucracies.

\footnotetext{
${ }^{39}$ Sending, The Politics of Expertise, p. 16.

${ }^{40}$ Barnett and Finnemore, Rules for the World, p. 21.

${ }^{41}$ On how this relationship is constructed or shaped by international bureaucracies themselves, see Sending and Lie, 'The limits of global authority'. On the role of the various perceptions of addressees on the authority of peer review mechanisms of IOs, see Jongen, 'The authority of peer reviews'. On the authority of public institutions to affect citizens' support, see Mirko Heinzel and Andrea Liese, 'Expert authority and support for COVID-19 measures in Germany and the UK: A survey experiment', West European Politics, First View (2021).
} 


\section{Perceived neutrality}

First, it is often assumed that expert authority relies on the appearance of an expert as neutral. ${ }^{42} \mathrm{~A}$ recent review of research findings on international bureaucracies states that ' $[\mathrm{i}$ ]n general, scholars have found the influence of international bureaucracies to be strongest when their expertise was perceived as being objective, impartial, fair or valid. ${ }^{43}$ This hypothesis goes back to Max Weber, who wrote that bureaucrats act in a professional (impersonal) capacity, indicating that they are acting on others' behalf instead of their own. ${ }^{44}$ The underlying causal mechanism rests on credibility. Information and advice are deemed less credible when they appear to be biased, and bureaucrats are only deemed trustworthy when they appear to be neutrally fulfilling their tasks. ${ }^{45}$ Perceived neutrality is thus regarded as a major source of expert authority.

Neutrality can refer to two different concepts: impartiality and objectivity. ${ }^{46}$ Each of them has been linked to expert authority ${ }^{47}$ and our article, therefore, addresses both. Impartiality is typically understood as setting one's own interests aside and treating all actors equally. ${ }^{48}$ An impartial bureaucracy is one that generates information and disseminates policy recommendations that appear to be unpartisan and thus unaligned with specific governments' preferences. ${ }^{49}$ Since the League of Nations, international bureaucracies have been designed to represent the opinions of all nations without favouring 'more narrowly defined national interests' ${ }^{50}$ It is assumed that impartiality signals an international bureaucracy's (or another IO body's) independence and generates credibility, thereby increasing the agency and influence of the latter. ${ }^{51}$ Objectivity is understood as scientific rationality. An objective bureaucracy is one that generates and disseminates information and policy recommendations that appear efficient, impersonal, and embodied in abstract rules and, hence, not as serving specific ideologies. ${ }^{52}$ It is assumed that perceived objectivity and authority are connected because politicisation and ideological bias undermine the credibility of an expert. ${ }^{53}$ Scholars argue that international bureaucracies are aware of this, and therefore spend considerable time on presenting their policy advice in objective and evidencebased ways, for instance, by quantifying information.

\footnotetext{
${ }^{42}$ Barnett and Finnemore, Rules for the World; Katharina Rietig, "Neutral” experts? How input of scientific expertise matters in international environmental negotiations', Policy Sciences, 47:2 (2014), pp. 141-60.

${ }^{43} \mathrm{de}$ Wit et al., 'International bureaucracy', p. 65.

${ }^{44}$ Max Weber, 'Bureaucracy', in Hans Gerth and C. Wright Mills (eds), From Max Weber: Essays in Sociology (Milton Park, Abingdon, Oxon: Routledge, 1991), pp. 196-244.

${ }^{45}$ Yoram Z. Haftel and Alexander Thompson, 'The independence of international organizations: Concept and applications', Journal of Conflict Resolution, 50:2 (2006), pp. 253-75 (p. 256).

${ }^{46}$ For a usage of these terms, see Barnett and Finnemore, Rules for the World, p. 69.

${ }^{47}$ Barnett and Finnemore link objectivity and expert authority when they hypothesise: 'The greater the appearance of depoliticization, the greater the authority associated with the expertise' (ibid., p. 25). And Zürn argues that 'states recognize the authority of international institutions when they provide valuable information and when they request from the perspective of impartiality to do something in order to achieve common goods or goals' (Zürn, 'From constitutional rule', p. 265).

${ }^{48}$ Emily Paddon Rhoads, Taking Sides in Peacekeeping: Impartiality and the Future of the United Nations (Oxford: Oxford University Press, 2016), p. 29; Erik Voeten, 'The impartiality of international judges: Evidence from the European Court of Human Rights', The American Political Science Review, 102:4 (2008), pp. 417-33 (p. 417).

${ }^{49}$ Mirko Heinzel, Jonas Richter, Per-Olof Busch, Hauke Feil, Jana Herold, and Andrea Liese, 'Birds of a feather? The determinants of impartiality perceptions of the IMF and the World Bank', Review of International Political Economy, First View (2020), p. 2.

${ }^{50}$ Thomas G. Weiss, 'International bureaucracy: The myth and reality of the international civil-service', International Affairs, 58:2 (1982), pp. 287-306 (p. 288).

${ }^{51}$ Cf. Kenneth W. Abbott and Duncan Snidal, 'Why states act through formal international organizations', Journal of Conflict Resolution, 42:1 (1998), pp. 3-32 (p. 20); Barnett and Finnemore, Rules for the World.

${ }^{52}$ Barnett and Finnemore, Rules for the World, pp. 68-9.

${ }^{53} \mathrm{Cf}$. Diane Stone, 'Private authority, scholarly legitimacy and political credibility: Think tanks and informal diplomacy', in Richard Higgott, Geoffrey Underhill, and Andreas Bieler (eds), Non State Actors and Authority in the Global System (London: Routledge, 2000), pp. 211-25.
} 
However, more recent literature has demonstrated that neutrality is more of a claim, a contested and changing norm, or even a myth than it is an inherent feature of international bureaucracies. ${ }^{54}$ Instead, it might vary and therefore might also account for variations in expert authority. To begin with, it would be naïve to assume that all international bureaucracies manage to present themselves as promoters of impartial and objective knowledge and advice. Several studies have found that organisational outputs are not free from interference by member states. ${ }^{55}$ They are also informed by ideologies, normative orientations, and organisational cultures. ${ }^{56}$ What follows from this is that international bureaucracies may sometimes fail to produce entirely impartial and objective advice. Furthermore, we assume that some bureaucracies are more successful than others in creating and upholding an appearance of neutrality, which is ultimately what counts.

Moreover, we assume that different states hold different views of bureaucracies' impartiality and objectivity. Varying perceptions of impartiality may reflect biases that occur due to interest heterogeneity and power asymmetries. States have different interests, and their ability to steer the policies of international bureaucracies into line with their preferences varies tremendously. They hold different positions of power in intergovernmental decision-making and are represented to different degrees within international bureaucracies. ${ }^{57}$ As a consequence, the less represented states will be unlikely to perceive the bureaucracy as impartial. ${ }^{58}$ Varying perceptions of objectivity may reflect the tendency to privilege certain values and ideologies. Stephen C. Nelson, for instance, has argued that ideational like-mindedness between IMF staff and domestic policymakers influences IMF staff decisions. ${ }^{59}$ We presume that such biases call a bureaucracy's objectivity into question, at least from the viewpoint of those states that hold a different ideational position.

Our survey indeed confirms that policy units of national ministries have very different perceptions of the impartiality and objectivity of international bureaucracies' work. A given international bureaucracy is often perceived quite differently by ministry officials from different countries, and there is similar variation across thematic areas. Figure A.4 in Appendix E (supplementary material) also shows that, in the case of impartiality, this variation cannot be sufficiently explained by formal rules that grant international bureaucracies formal independence. Hence, we argue that we have to consider stakeholders' perceptions of international bureaucracies' impartiality and objectivity when seeking to explain international bureaucracies' de facto expert authority.

Based on these explanations, we derive the following hypotheses:

Hypothesis 1a. The more impartial the work of an international bureaucracy is perceived to be, the higher the international bureaucracy's de facto expert authority.

Hypothesis 16 . The more objective the work of an international bureaucracy is perceived to be, the higher the international bureaucracy's de facto expert authority.

\footnotetext{
${ }^{54}$ Bauer and Ege 'Bureaucratic autonomy'; Dijkstra, 'Collusion in international organizations'; see also Weiss, 'International bureaucracy'; Barnett and Finnemore, Rules for the World, p. 21; Paddon Rhoads, Taking Sides in Peacekeeping.

${ }^{55}$ Axel Dreher, Jan-Egbert Sturm, and James R. Vreeland, 'Global horse trading: IMF loans for votes in the United Nations Security Council', European Economic Review, 53:7 (2009), pp. 742-57; Robert K. Fleck and Christopher Kilby, 'World Bank independence: A model and statistical analysis of US influence', Review of Development Economics, 10:2 (2006), pp. $224-40$.

${ }^{56}$ Jeffrey M. Chwieroth, 'Professional ties that bind: How normative orientations shape IMF conditionality', Review of International Political Economy, 22:4 (2015), pp. 757-87.

${ }^{57}$ Michal Parízek, 'Control, soft information, and the politics of international organizations staffing', The Review of International Organizations, 12:4 (2017), pp. 559-83.

${ }^{58}$ Ibid., p. 563.

${ }^{59}$ Stephen C. Nelson, 'Playing favorites: How shared beliefs shape the IMF's lending decisions', International Organization, $68: 2$ (2014), pp. 297-328.
} 


\section{Perceived impact}

A second explanation for international bureaucracies' de facto expert authority is their perceived contribution to effectively addressing global challenges, which we call perceived impact. The underlying causal mechanism rests on the expectation that international bureaucracies help to solve policy problems. Thus, expected benefits are the main reason for the addressees of an international bureaucracy's advice to grant authority to the actor in the first place. ${ }^{60}$ Once an authority relationship is established, it continues to rest on the ability of the actor to serve 'some valued and legitimate social purpose'. ${ }^{61}$ Accordingly, international bureaucracies' expert authority is called into question when they are perceived to perform badly. ${ }^{62}$ We find the same expectation for national bureaucracies in the public administration and management literature. ${ }^{63}$ Hence, we assume that ministry officials who have to propose solutions to specific policy problems turn to those international bureaucracies whose performance they value.

When evaluating IO performance or regime effectiveness, the literature generally focuses on outputs, outcomes, or impacts. ${ }^{64}$ We focus on perceptions of impact. While outputs comprise various activities of international bureaucracies such as publications or policy programs, outcomes refer to the desired behavioural changes induced by these outputs, for instance, the implementation of international bureaucracies' policy recommendations by states. Impacts refer to the extent to which organisational outputs eventually bring about a solution to the underlying problem in the broader socioeconomic or ecological environment. Impact is often also referred to as problem-solving effectiveness. ${ }^{65}$

We opt to focus on the impact dimension since the ultimate goal of global governance and IOs' mandate is to address global challenges. IOs are created to 'help guide states through the challenging maze posed by the current international agenda by developing effective road maps ${ }^{66}$ Furthermore, we consider measures that focus on the output and outcome dimensions to be unsuitable indicators for our purposes because they conceptually overlap with our dependent variable. Policy advice is an organisational output, while its consideration by national bureaucrats is a potential outcome. Thus, any evaluation of these two would likely intersect with the concept of expert authority and could lead to problems of endogeneity.

International bureaucracies' perceived impact is less prone to these problems. This holds particularly for impact at the global level, which is our focus here. It appears conceivable that more authority contributes to a higher impact at the national level. Yet far more conditions would have to be met for de facto expert authority to have a greater impact at the global level. First, policy units, as the addressees of expert authority, would have to comply and implement the international bureaucracies' policy advice. The mere consideration of international bureaucracies' advice - our measure for deference to authority - does not necessarily result in compliance. Obviously, while

\footnotetext{
${ }^{60}$ Lake, 'Rightful rules', p. 594f; Abbott and Snidal, 'Why states act'.

${ }^{61}$ Barnett and Finnemore, Rules for the World, p. 21; see also Zürn, 'From constitutional rule', p. 266.

${ }^{62}$ Deborah D. Avant, Martha Finnemore, and Susan K. Sell, 'Who governs the globe?', in Deborah D. Avant, Martha Finnemore, and Susan K. Sell (eds), Who Governs the Globe? (Cambridge: Cambridge University Press, 2010), pp. 1-31 (p. 24).

${ }^{63}$ Poul Aaes Nielsen and Christian Botcher Jacobsen, 'Zone of acceptance under performance measurement: Does performance information affect employee acceptance of management authority?', Public Administration Review, 78:5 (2018), pp. 684-93.

${ }^{64}$ Jonas Tallberg, Thomas Sommerer, Theresa Squatrito, and Magnus Lundgren, 'The performance of international organizations: A policy output approach', Journal of European Public Policy, $23: 7$ (2016), pp. 1077-96; Oran Young, 'Inferences and indices: Evaluating the effectiveness of international environmental regimes', Global Environmental Politics, 1:1 (2001), pp. 99-121. See also David Easton, A Systems Analysis of Political Life (London, Sydney, and New York, NY: 1965), pp. 351-2.

${ }^{65}$ Frank Biermann, Bernd Siebenhüner, Steffen Bauer, Per-Olof Busch, Sabine Campe, Klaus Dingwerth, Torsten Grothmann, Robert Marschinski, and Mireia R. Taradell, 'Studying the influence of international bureaucracies: A conceptual framework', in Biermann and Siebenhüner (eds), Managers of Global Change, pp. 37-74 (p. 41); Tallberg et al., 'The performance of international organizations', p. 1079.

${ }^{66}$ Peter M. Haas and Ernst B. Haas, 'Learning to learn: Improving international governance', Global Governance, 1:3 (1995), pp. 255-85 (pp. 258-9).
} 
ministry officials are important gatekeepers, they can neither order nor decide alone on the implementation of policies. Second, even when advice is acted upon, this may have no effect on international bureaucracies' global impacts, in the sense of their ability to effectively address a given global problem. A frequently cited explanation for this lack is unambitious policy goals.

By contrast, there is a much more direct relationship between international bureaucracies' perceived global impact and their de facto expert authority over policy units in national ministries, and the demands that must be met for this relationship to unfold are much lower. Policy units only need to be familiar with the international bureaucracy and to have formed an assessment of its global impact. Therefore, we study the relationship between the perceptions of international bureaucracies' global impact and their de facto expert authority among national policy units.

We thus hypothesise:

Hypothesis 2. The higher an international bureaucracy's global impact is perceived to be, the higher its de facto expert authority.

\section{Potential knowledge asymmetries}

A third explanation for expert authority refers to knowledge asymmetries that are caused by factors such as a lack of and demand for cognitive resources. The idea of specific (and, thus, rare) expertise as an important source of power features prominently in the public administration literature and in theories of delegation. ${ }^{67}$ This idea can be traced back to the Weberian paradigm of bureaucratic influence, in which information asymmetries are seen as central for bureaucracies' influence because bureaucrats possess specialised knowledge and skills that elected officials lack. ${ }^{68}$ The literature on the potential power of IOs and international bureaucracies seems to presume that international bureaucracies possess a 'comparative informational advantage ${ }^{69}$ in terms of specialised knowledge, training, and experience vis-à-vis stakeholders. ${ }^{70}$ Yet, such knowledge asymmetries should not be taken for granted since governments vary in terms of their own cognitive resources. ${ }^{71}$ Since all international bureaucracies in our sample provide policy advice, we opt to study the asymmetry from the perspective of the state 'demanding' the expertise, and not the perspective of the bureaucracy 'supplying' the expertise.

Following from the above considerations, one may expect international bureaucracies to enjoy more expert authority in states that lack cognitive resources or expertise within their government ministries and therefore have a higher demand for external information and advice. These are usually states with comparatively low state budgets, whose ministries are less well equipped in terms of human and financial resources. Low state budgets also impair the production of knowledge within the country. They influence the number of staff and experts in the ministries, and the 'possibilities for states to buy in external expertise. ${ }^{72}$ For example, IMF staff members report that most developing economies lack a tax policy unit 'tasked to guide and inform the tax policy debate, based on facts, independent data analysis, and multidisciplinary efforts'. ${ }^{73}$ Governments that lack resources,

\footnotetext{
${ }^{67}$ John D. Huber and Charles R. Shipan, Deliberate Discretion? The Institutional Foundations of Bureaucratic Autonomy (Cambridge: Cambridge University Press, 2002).

${ }^{68}$ Weber, 'Bureaucracy', pp. 854-5.

${ }^{69}$ Derek Beach, 'The unseen hand in treaty reform negotiations: The role and influence of the Council Secretariat', Journal of European Public Policy, 11:3 (2004), pp. 408-39 (p. 411).

${ }^{70} \mathrm{Xu}$ Yi-Chong and Patrick Weller, “To be, but not to be seen": Exploring the impact of international civil servants', Public Administration, 86:1 (2008), pp. 35-51 (p. 46); Avant et al., 'Who governs the globe?', p. 12.

${ }^{71}$ Hylke Dijkstra, 'Shadow bureaucracies and the unilateral control of international secretariats: Insights from UN peacekeeping', Review of International Organizations, 10:1 (2015), pp. 23-41.

${ }^{72}$ Diana Panke, 'Dwarfs in international negotiations: How small states make their voices heard', Cambridge Review of International Affairs, 25:3 (2012), pp. 313-28 (pp. 315-16).

${ }^{73}$ Martin Grote and International Monetary Fund/Fiscal Affairs Department, How to Establish a Tax Policy Unit (Washington, DC: IMF, 2017), p. 2.
} 
including expertise, often turn to international bureaucracies for assistance. ${ }^{74}$ Not only do many international bureaucracies offer advice; in contrast to private actors, they usually provide it free of charge.

Finally, it is plausible that knowledge asymmetries render it more difficult for ministries to validate other actors' advice. They are therefore more likely to accept policy advice independent of an examination of its content and mainly because it comes from a specific source. Consequently, we expect that countries with more limited resources are more likely to ascribe expert authority to an international bureaucracy.

Therefore, we propose the following hypothesis:

Hypothesis 3. The higher the potential knowledge asymmetry to the advantage of the international bureaucracy, the higher the international bureaucracy's de facto expert authority.

\section{Research design}

We used a cross-sectional survey among ministries in a representative sample of 121 countries to collect the data. The choice of this data collection method was mainly motivated by the conceptualisation of de facto expert authority in the literature and the related implications for its operationalisation and measurement. First, given that the 'problem of observational equivalence between authority and other forms of social control runs deep', ${ }^{75}$ any measurement of de facto expert authority must be distinguishable from other forms of power, such as coercion, incentives, and content-dependent persuasion. Second, any measurement of de facto expert authority must be suitable to grasp its relational character. Third, de facto expert authority must not be equated with the communication of knowledge-based policy advice or the mere possession of knowledge by the international bureaucracy. Experts must be recognised as such by their audiences. Such recognition may rest either on observable attributions or on the mere assumption that a superior actor has specialised and reliable knowledge. ${ }^{76}$ Fourth, authority should not only be derived from its effects. It would be insufficient to conclude that every observed instance of compliance with international bureaucracies' recommendations stems from authority without studying whether compliance is related to the prior recognition of these bureaucracies as experts. ${ }^{77}$ Fifth, deference to authority does not mean that actors have to comply with the requests of a superior actor; it suffices when they are 'carefully listening to what they say'. ${ }^{78}$ Hence, it is not necessary that they eventually adopt and implement the policies, but only that they consider what international bureaucracies recommend. ${ }^{79}$

Survey questions can be asked in a way that allows us to distinguish expert authority from other forms of power, for instance, coercion and related concepts, such as expertise. This helps to avoid the problem of observational equivalence. Moreover, three of our main hypotheses (impartiality, objectivity, and impact) are based on perceptions, which can also be captured by a survey.

\footnotetext{
${ }^{74}$ Alexander Thompson, 'Coercion through IOs: The Security Council and the logic of information transmission', International Organization, 60:1 (2006), pp. 1-34 (p. 1).

${ }^{75}$ Ian Hurd, 'Theories and tests of international authority', in Bruce Cronin and Ian Hurd (eds), The UN Security Council and the Politics of International Authority (London: Routledge, 2008), pp. 23-40 (p. 32).

${ }^{76}$ Sending, The Politics of Expertise, pp. 21, 26; Carey Doberstein, 'Whom do bureaucrats believe? A randomized controlled experiment testing perceptions of credibility of policy research', The Policy Studies Journal, 45:2 (2017), pp. $384-405$.

${ }^{77}$ Biermann and Siebenhüner, 'The influence of international bureaucracies'; Carraro and Jongen, 'Leaving the doors open', p. 618; Ecker-Ehrhardt, "But the UN said so"'.

${ }^{78}$ Daniel Viehoff, 'Authority and expertise', The Journal of Political Philosophy, 24:4 (2016), pp. 406-26 (p. 412 ).

${ }^{79}$ See Carraro and Jongen, 'Leaving the doors open', p. 616.
} 


\section{Selection of international bureaucracies and respondents}

The survey comprises nine global bureaucracies in four thematic areas of agricultural policy and four thematic areas of financial policy. ${ }^{80}$ The international bureaucracies were selected in a process consisting of multiple and interrelated steps. To enable comparison, we preselected a list of international bureaucracies and thematic areas. If we had not done so, survey respondents might have only assessed the work of the international bureaucracy they knew best or disliked most, and the bureaucracies would have differed from respondent to respondent. To ensure comparability, we selected broad policy fields and specific thematic areas in which several international bureaucracies with global reach were active. For our analysis, it was important that these international bureaucracies themselves claimed to have authority in a particular policy field and thus qualified as candidates for expert authority: it would have made little sense to examine the conditions under which, for instance, the World Tourism Organization is recognised as an expert authority in debt management policy. Therefore, in the preselection process, we verified that each international bureaucracy in our sample had communicated policy advice by studying websites, documents, and flagship publications. We chose only those bureaucracies that generally address their advice to all states worldwide, and we only selected thematic areas that were specific enough that we could match them with policy units in national ministries as potential addressees of policy advice. $^{81}$ Our final selection met these criteria best.

In order to assess international bureaucracies' de facto expert authority, the survey targeted the policy units in national ministries that work in the aforementioned thematic areas. We sent an invitation to participate in the survey to those officials chiefly responsible for the thematic areas in their country. Most of these officials held a position as head of the respective policy unit in their ministry. We chose this group of respondents for several reasons. First, ministry officials are among the most important addressees and recipients of international bureaucracies' policy advice. Additionally, they play a key role as 'gate-keepers of policy research and analysis' at the national level, where they brief government officials. ${ }^{82}$ They can thus be regarded as important interlocutors and policymakers. Second, we were interested in the prevalent practices of policy units in national ministries rather than individual, personal assessments. The heads of policy units can best provide information on the practices of their units. Therefore, the questionnaire explicitly requested that respondents indicate the prevalent practices in their respective units. ${ }^{83}$ We consider our respondents to be highly qualified to make these assessments given their longstanding work experience. Almost half of the respondents had more than ten years of work experience in the respective thematic area and had been working in the ministry for at least five years. Only 3 per cent of the respondents had less than one year of thematic work experience. Furthermore, we found no pattern between the respondents' level of seniority and international bureaucracies' expert authority.

The invitations to participate in the survey were personally addressed to the heads of the respective ministry unit, and most were sent out by mail. ${ }^{84}$ The invitations also included a

\footnotetext{
${ }^{80}$ The selected thematic areas are agribusiness policy, biodiversity policy in agriculture, bioenergy policy in agriculture, climate change policy in agriculture, banking regulation policy, debt management policy, monetary policy, and tax policy. The selected international bureaucracies are the BIS, FAO, IFAD, IMF, OECD, UNCTAD, UN DESA, UNEP, and the World Bank (Appendix A). Additionally, the survey includes evaluations of nine regional bureaucracies, which are not included in this article.

${ }^{81}$ All our survey questions referred to these specific thematic areas. Besides ensuring comparability of answers, we believe that this phrasing helped the respondents to think about concrete situations rather than having to rely on somewhat abstract evaluations. Depending on the thematic area and the organisational structure of the different national authorities, our survey targeted departments in ministries, public agencies, and central banks. For reasons of simplicity, we use the term 'ministry official' for all survey respondents.

${ }^{82}$ Doberstein, 'Whom do bureaucrats believe?', p. 398.

${ }^{83}$ Some heads of units explicitly indicated that they had worked with their team in answering the questionnaire.

${ }^{84}$ In a few instances, we were unable to send invitations by mail. In these instances, we sent the invitation by email or fax.
} 
paper questionnaire that could be sent back by mail, fax, or email, but most respondents used the online questionnaire. The questionnaire was available in English, French, German, and Spanish. By using this approach, we achieved an extraordinarily high response rate of 38 per cent, which corresponds to 362 received questionnaires and 1,785 individual observations for the nine international bureaucracies (see also Appendix $\mathrm{C}$ in the supplementary material for further details on the response rate).

Overall, our survey sample included policy units in ministries in 121 countries. The countries were selected using a stratified sampling process, whereby the survey population (all UN member states) was stratified according to the UN region and World Bank income classification (see Appendix A in the supplementary material for further details).

\section{Survey design}

Our survey uses a single-source, self-report, cross-sectional research design. It provides information on the dependent variable and three of the independent variables, which may result in a spurious covariance between independent and dependent variables. ${ }^{85}$ The risk of so-called common method variance (CMV) or common method bias can best be avoided when measures are collected from different sources or when the predictor and the criterion, that is, the independent and the dependent variables, are measured separately. Yet, given that this was a global survey of high-ranking ministry officials who have limited time available, it was not feasible to split groups (that is, ask two officials within the same unit) or to split the questionnaire and ask respondents to answer the separate parts at different points in time.

To assess the risk of CMV, we conducted a Harman's single-factor test based on the survey data collected. The test gives no indication that CMV is an issue. However, since this test has some limitations, we took several precautions in the design stage to avoid the four main causes of $\mathrm{CMV}^{86}$ as recommended in the literature. ${ }^{87}$

First, regarding common rater effects, we implemented procedural remedies for social desirability bias, leniency, and acquiescence by assuring respondent anonymity and detailing our high standards of privacy and data protection. ${ }^{88}$ We also selected respondents with high expertise to answer our survey questions. Survey research has found that accurate answers depend on matching 'the difficulty of the task of answering the question with the capability of the respondent' and on motivating respondents to participate by providing clear instructions and stressing how important their unique perspectives are. ${ }^{89}$ Second, we sought to reduce item ambiguity and related comprehension problems by formulating the questions as concisely as possible (see below). Respondents were also offered various opportunities to clarify any comprehension questions throughout the process of participation. ${ }^{90}$ We further used different response scale anchors for different constructs to avoid automatic response consistency. ${ }^{91}$ Third, we controlled for measurement context effects by carrying out a self-administered survey. We chose computeradministered questionnaires or paper-and-pencil questionnaires instead of verbal or face-to-face

\footnotetext{
${ }^{85}$ Philip M. Podsakoff, Scott B. McKenzie, Nathan P. Podsakoff, and Jeong-Yoon Lee, 'Common method bias in behavioral research: A critical review of the literature and recommended remedies', Journal of Applied Psychology, 88:5 (2003), pp. 879903.

${ }^{86}$ Ibid., pp. 881-5.

${ }^{87}$ Sea-Jin Chang, Arjen van Witteloostuijn, and Lorraine Eden, 'From the Editors: Common method variance in international business research', Journal of International Business Studies, 41:2 (2010), pp. 178-84; Philip M. Podsakoff, Scott B. MacKenzie, and Nathan P. Podsakoff, 'Sources of method bias in social science research and recommendations on how to control it', Annual Review of Psychology, 63 (2012), pp. 879-903.

${ }^{88}$ Podsakoff et al., 'Common method bias', p. 888.

${ }^{89}$ Podsakoff et al., 'Sources of method bias', p. 562.

${ }^{90}$ Chang et al., 'From the Editors', p. 180.

${ }^{91}$ Podsakoff et al., 'Sources of method bias', p. 551.
} 
interviews to avoid the problem of respondents giving biased answers due to the presence of an interviewer. $^{92}$

While we employed a range of remedies for item context effects, some additional remedies were not used due to lower feasibility in expert surveys. For instance, we opted against counterbalancing or randomising question order because this would have made it impossible to progress from general to specific (and more sensitive) questions, an approach that is recommended in the survey literature. It would also have required the use of survey software, which was again not feasible given that the majority of ministry officials targeted in our survey had to be contacted by mail, and many respondents from the Global South preferred paper-and-pencil questionnaires. ${ }^{93}$

Finally, we followed the advice in the survey literature to employ single-item measures for our constructs. While multi-item constructs are preferable under certain circumstances, ${ }^{94}$ they typically require established valid measures, and bear the risks of sampling bias and consistency motifs: a lengthy survey may overload or bore respondents, thus reducing response rates and accuracy. ${ }^{95}$ Single measures have the advantage of being more parsimonious and less timeconsuming, but also require that each measure captures the construct as precisely as possible. We followed the suggestion in the literature to ask experts to select the item that most closely captures the construct of interest. ${ }^{96}$ We developed the survey questions with feedback from a range of political scientists and public officials at the subnational level before pretesting the survey questions with officials from several world regions working at ministries other than those included in our survey.

\section{Dependent variable}

To capture our dependent variable - expert authority as a social relationship between authority holder and subordinate actor - we constructed the survey question to include both the recognition of international bureaucracies as experts and the deference to their advice. We directly asked national ministry officials - as the addressees of international bureaucracies' policy advice whether, and to what extent, they had considered an international bureaucracy's advice in the work of their unit (action) because they regard the international bureaucracy to be an expert in the given thematic field (attribution). ${ }^{97}$ The seven response categories for this question refer to seven different degrees of EXPERT AUTHORITY (from high to no expert authority).

Our question leads to a rather strict measure. The concept of authority is source-specific. This means that a given entity holds authority without any need for persuasion, and that the

\footnotetext{
${ }^{92}$ Frauke Kreuter, Stanley Presser, and Roger Tourangeau, 'Social desirability bias in CATI, IVR, and web surveys: The effects of mode and question sensitivity’, Public Opinion Quarterly, 72:5 (2008), pp. 847-65.

${ }^{93}$ Questionnaires including a formal cover letter sent by mail are regarded as more professional when surveying public administrations, whereas unsolicited email surveys are frequently considered spam and deleted immediately. Moreover, email addresses of ministry officials are often not publicly available (Gareth Enticott, 'Researching local government using electronic surveys', Local Government Studies, 29:2 (2003), pp. 52-67 (p. 57)). While nearly 68 per cent of our respondents submitted the questionnaire online, a fourth of all respondents preferred to scan and email the paper-pencil-questionnaire, and 7 per cent sent the questionnaire back by mail. The use of survey software would thus not have been feasible.

${ }^{94}$ Christoph Fuchs and Adamantios Diamantopolous, 'Using single-item measures for construct measurement in management research', DBW: Die Betriebswirtschaft, 69:2 (2009), pp. 195-210.

${ }^{95}$ Adamantios Diamantopolous, Marko Sarstedt, Christoph Fuchs, Petra Wilczynski, and Sebastian Kaiser, 'Guidelines for choosing between multi-item and single-item scales for construct measurement: A predictive validity perspective', Journal of the Academy of Marketing Science, 40:3 (2012), pp. 434-49 (p. 435).

${ }^{96}$ Ibid., p. 436.

${ }^{97}$ See Appendix B (supplementary material) for the exact wording of the questionnaire. To validate the measure of the dependent variable, we cross-checked the answers with items that are not included in the analysis. For instance, we additionally asked respondents about the extent to which they took policy advice into consideration (action), independent of the underlying reason, in one question, and the level to which they regard the international bureaucracies to possess expertise (attribution) in a separate question. We excluded the few answers in which the value for the question on expert authority was higher than the value for the question on consideration of policy advice (irrespective of the motive).
} 


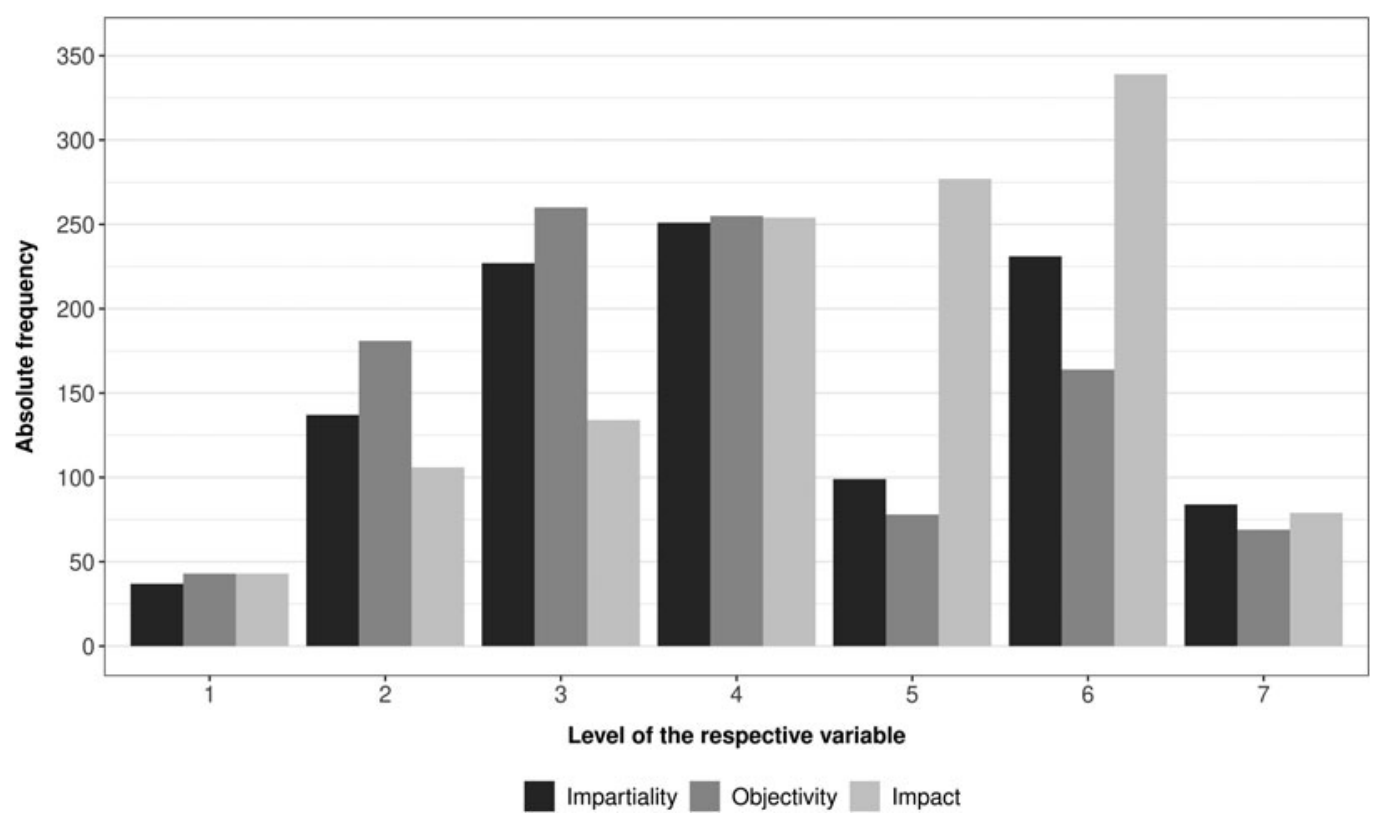

Figure 3. Absolute frequencies of the survey-based independent variables. ${ }^{98}$

addressees of its policy advice generally consider that advice without a thorough examination of its content. We therefore asked if ministry officials follow the policy advice because they regard the international bureaucracy as an expert whose advice does not require further examination. We chose a wording that helped us to exclude other forms of power, such as conditionality, enforcement, and pressure, which could also play a role in the consideration of policy advice. These other forms of power were, however, the subject of separate questions and form part of our robustness checks.

\section{Independent variables}

Data on the perceived impartiality, objectivity, and impact of an international bureaucracy were also collected by means of separate survey questions. IMPARTIALITY (hypothesis 1a) is operationalised as the extent to which the bureaucracy is perceived as not representing some countries' interests more than others. OBJECTIVITY (hypothesis $1 \mathrm{~b}$ ) is operationalised as the degree to which the bureaucracy is perceived as not being biased in favour of certain values or ideologies. The IMPACT of an international bureaucracy (hypothesis 2) is operationalised as its perceived contribution to effectively addressing current challenges at the global level. Figure 3 shows the absolute frequencies of the three survey-based independent variables.

Data on the knowledge asymmetry hypothesis (hypothesis 3) were not collected through the survey, since self-reports on the cognitive resources of survey respondents (or the ministry they work for) and their self-perception as experts would have been highly prone to the influence of both social desirability and leniency bias. Instead, we measured ASYMMETRY by the inverse of the country's gross domestic product (GDP) and taking the natural log of this ratio. ${ }^{99}$ In related studies, this indicator is a well-established proxy for measuring the degree to which a country lacks cognitive resources and therefore lacks alternatives to external expertise and advice. The

\footnotetext{
${ }^{98}$ The survey-based variables were measured on a scale from 1 (low) to 7 (high).

${ }^{99}$ Data taken from World Bank Open Data Website, available at: \{http://data.worldbank.org\} accessed 3 May 2018.
} 
indicator is assumed to reflect the human resources within a ministry as well as the financial resources available to ministry staff to develop their expertise. ${ }^{100}$ Due to limited data availability and quality, we opted for this indicator instead of other conceivable indicators, such as gross domestic expenditure on research and experimental development (GERD) from the UNESCO Institute for Statistics (UIS) database ${ }^{101}$ or bibliometric indicators, for example, from the SCImago Journal \& Country Rank database. ${ }^{102}$ Nevertheless, we checked the validity of our indicator and found that the GERD indicators and the bibliometric indicators highly correlate with GDP (average Pearson's $r$ at 0.85 , see Appendix F in the supplementary material).

\section{Control variables, fixed effects, and clustered standard errors}

We include a range of control variables in our regression models to test the robustness of our results and to correct for a possible omitted variable bias.

First, we test whether the correlations of IMPARTIALITY, OBJECTIVITY, IMPACT, and ASYMMETRY with EXPERT AUTHORITY hold when other motives to consider an international bureaucracy's policy advice are also present and coincide. To this end, we control for: (i) the congruence of the bureaucracy's policy advice with the policy preferences of the official's country (CONGRUENCE); (ii) the IO's overall potential to induce deference by means of conditionality and/or enforcement (COERCION); ${ }^{103}$ and (iii) potential third-party pressure to act on the advice from a specific international bureaucracy (PRESSURE). ${ }^{104}$ We acknowledge that deference to an international bureaucracy's advice might be driven by other instruments of an IO (coercion), the orchestration of third parties (pressure), or the tailoring of advice to domestic policy preferences (congruence). For example, the IMF and the World Bank, which are included in our sample, are known for their conditionality, while the OECD is known for orchestrating peer pressure.

Second, to account for heterogeneity across countries, we include variables at the country level. These comprise countries' level of development, measured by their GDP per capita (log), ${ }^{105}$ countries' political rights and civil liberties based on Freedom House data, ${ }^{106}$ countries' level of corruption (CORRUPTION (WGI) ${ }^{107}$ and CORRUPTION (TI), ${ }^{108}$ and the importance of the respective thematic area on the government's policy agenda as indicated by respondents in the survey (IMPORTANCE). ${ }^{109}$

Third, we include fixed effects for each international bureaucracy in each thematic area in all models. Given that institutional design variables and particularities of the policy field play a

\footnotetext{
${ }^{100}$ We are not interested in measuring a country's level of development, but rather its lack of cognitive resources and resulting need for outside advice, which can exist despite a country's high level of development. Therefore, in the context of this study, we regard total GDP to be more adequate because it considers both a country's financial means and the size of its population, which directly affect the size of its ministries and, hence, its human resources. We additionally performed the regression analysis using GDP per capita. It does not substantially change the results (only the coefficient of the variable ASYMMETRY becomes insignificant in Model 6, with a p-value of 0.12 , while it is still positively correlated with EXPERT AUTHORITY).

${ }^{101}$ Database available at: $\{$ http://uis.unesco.org/ $\}$ accessed 25 January 2017.

${ }^{102}$ Database available at: $\{$ http://www.scimagojr.com/countryrank.php/\} accessed 21 September 2016.

${ }^{103}$ Formally, international bureaucracies do not possess any power to enforce decisions. Therefore, we refer to the IO as a whole.

${ }^{104}$ We collected data on these control variables via our survey as well. See Appendix B in the supplementary material for the exact wording of the questions.

${ }^{105}$ Data taken from the World Bank Open Data Website, available at: \{http://data.worldbank.org\} accessed 3 May 2018.

${ }^{106}$ Data taken from the Freedom House Website, available at: \{https://freedomhouse.org/\} accessed 29 August 2016.

${ }^{107}$ Data taken from the Worldwide Governance Indicators Project, available at: \{http://info.worldbank.org/governance/wgi/ index.aspx\#home\} accessed 25 October 2017.

${ }^{108}$ Data taken from the Transparency International Website, available at: $\{$ https://www.transparency.org/research/cpi/overview\} accessed 25 October 2017.

${ }^{109}$ See Appendix B (supplementary material) for the exact wording of the question.
} 
minor role in the theoretical debate on de facto expert authority, we lack testable assumptions as to how they affect the outcome of interest, that is, the expert authority relationship between a national ministerial unit and an international bureaucracy. Fixed effects take into account that international bureaucracies are likely to differ in institutional design, financial and human resources, and activities in the different thematic areas. ${ }^{110}$ As described above, our data reveal variation in expert authority across international bureaucracies in thematic areas (see Figures A1 in Appendix B and A2 in Appendix D in the supplementary material).

Fourth, we use clustered standard errors on the respondent level in all models to correct for heteroscedasticity due to respondent-specific influences. We do so for two reasons. First, in our questionnaire, each respondent evaluated several international bureaucracies, and thus, the evaluations may not be independent. For example, the respondent might hold a certain view about multilateral institutions in general. Second, research on public attitudes towards IOs has shown that survey respondents use heuristics based on their experiences with more familiar national institutions when assessing IOs with which they might be less familiar. ${ }^{111}$ We assume that our survey participants (ministry officials working in the same thematic areas as the international bureaucracies that we asked about) are much more familiar with IOs than survey participants in the research on public attitudes to IOs (citizens or societal actors). Nevertheless, we aimed at minimising the possibility that respondents used national heuristics and designed our survey questions accordingly. Not only did we offer the answer category 'advice or work not known'; we also avoided questions involving abstract concepts, such as authority or neutrality. Instead, our questions were worded specifically to encourage respondents to think of particular qualities of international bureaucracies or their own personal interactions with them.

\section{Results}

To explain international bureaucracies' de facto expert authority, we ran several ordinary least square (OLS) regressions. First, we present the estimates of a model focusing only on the four main explanatory variables discussed above: IMPARTIALITY, OBJECTIVITY, IMPACT, and ASYMMETRY (Model 1). In a second step, we include the three control variables: CONGRUENCE, COERCION, and PRESSURE. Table 1 displays the regression results for Model 1 and 2, and Figure 4 illustrates the standardised coefficients and 95 per cent confidence bands based on the estimations of both models.

Overall, there is considerable support for the importance of explanations based on the perceived impact and objectivity of international bureaucracies and the knowledge asymmetry in favour of the international bureaucracy, but the correlations are not equally strong. International bureaucracies' IMPACT is by far the strongest determinant of EXPERT AUTHORITY, with highly significant and positive coefficients in both models, although the coefficient decreases from 0.534 (Model 1) to 0.360 when including the control variables (Model 2). Thus, the higher the perceived global impact, the greater the international bureaucracies' expert authority among policy units in national ministries, all else equal. The coefficients for OBJECTIVITY are also positive and statistically significant in both models. Here, the coefficient increases slightly from 0.115 (Model 1) to 0.144 (Model 2). Hence, the less an international bureaucracy's work is perceived to be biased towards particular values and ideologies, the greater its expert authority. Knowledge asymmetries also influence international bureaucracies' expert authority: the more limited a state's cognitive resources, the more expert authority international

\footnotetext{
${ }^{110}$ For a discussion of their varying design, see Michael W. Manulak, 'Leading by design: Informal influence and international secretariats', Review of International Organizations, 12:4 (2017), pp. 497-522.

${ }^{111}$ See, for example, Bernd Schlipphak, 'Measuring attitudes toward regional organizations outside Europe', Review of International Organizations, 10:3 (2015), pp. 351-75.
} 
Table 1. Explanatory models for expert authority.

\begin{tabular}{|c|c|c|}
\hline & Model 1 & Model 2 \\
\hline IMPARTIALITY & $\begin{array}{l}-0.039 \\
(0.057)\end{array}$ & $\begin{array}{l}-0.049 \\
(0.067)\end{array}$ \\
\hline OBJECTIVITY & $\begin{array}{l}0.115^{\star} \\
(0.056)\end{array}$ & $\begin{array}{l}0.144^{\star} \\
(0.065)\end{array}$ \\
\hline IMPACT & $\begin{array}{l}0.534^{\star \star \star} \\
(0.043)\end{array}$ & $\begin{array}{l}0.360^{\star * *} \\
(0.058)\end{array}$ \\
\hline ASYMMETRY & $\begin{array}{l}0.180^{\star \star \star *} \\
(0.051)\end{array}$ & $\begin{array}{l}0.155^{\star \star} \\
(0.057)\end{array}$ \\
\hline COERCION & & $\begin{array}{l}0.104^{\prime} \\
(0.055)\end{array}$ \\
\hline CONGRUENCE & & $\begin{array}{l}0.212^{\star \star \star} \\
(0.049)\end{array}$ \\
\hline PRESSURE & & $\begin{array}{l}0.123^{\star \star} \\
(0.042)\end{array}$ \\
\hline Intercept & $\begin{array}{l}0.209 \\
(0.154)\end{array}$ & $\begin{array}{l}0.430^{\star \star} \\
(0.137)\end{array}$ \\
\hline $\mathrm{R}^{2}$ & 0.452 & 0.512 \\
\hline Adj. $R^{2}$ & 0.423 & 0.473 \\
\hline Num. obs. & 873 & 644 \\
\hline
\end{tabular}

Notes: OLS regressions with two-tailed significance for estimates. ' $p<0.1 ;{ }^{\star} p<0.05 ;{ }^{\star \star} p<0.01 ;{ }^{\star \star \star} p<0.001$. Standardised coefficients with robust standard errors clustered by respondent (in parentheses). Fixed effects for the international bureaucracies in their thematic areas are omitted from the table.

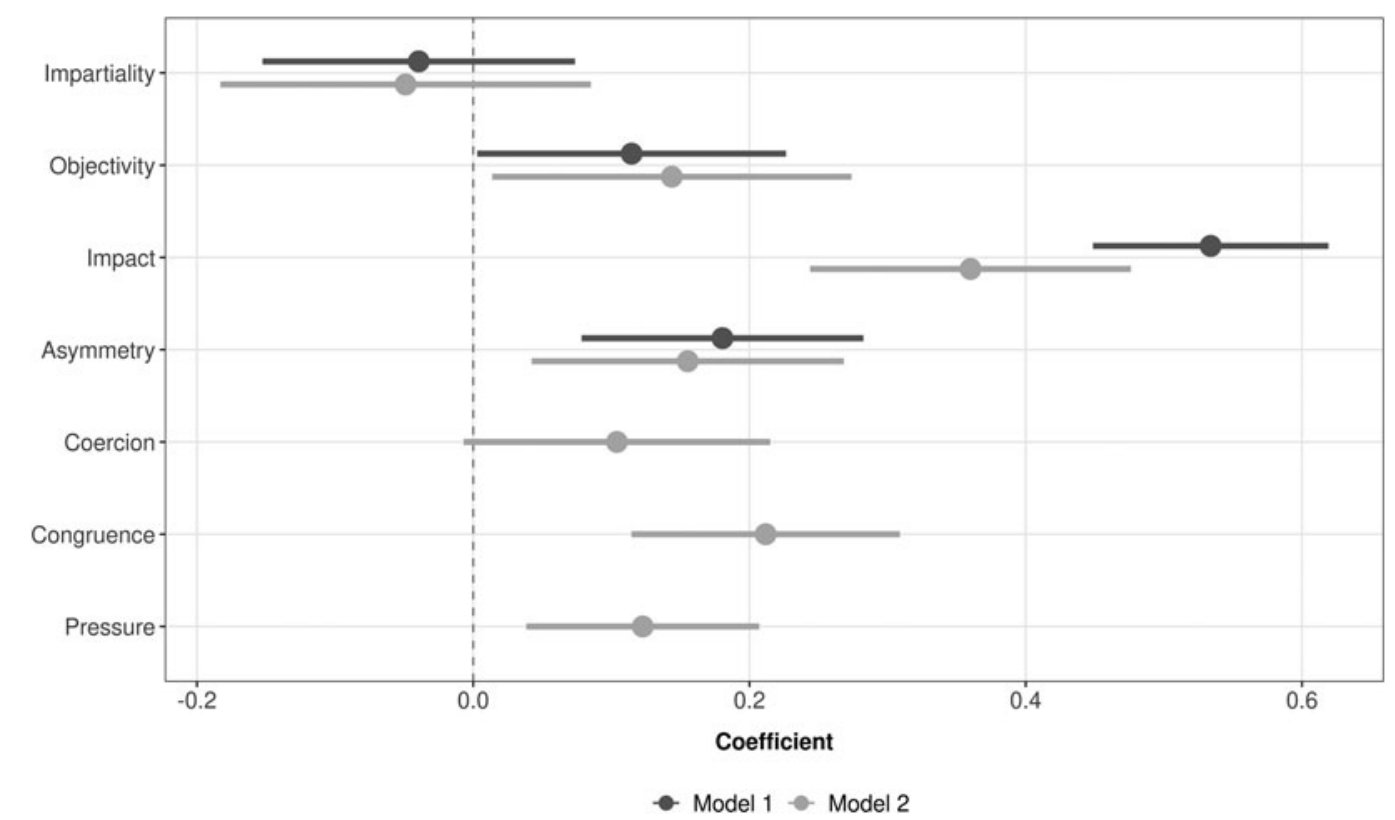

Figure 4. Regression coefficient plots of Models 1 and 2.

Notes: Dots represent standardised effect sizes of each explanatory variable with 95 per cent confidence intervals as estimated from Models 1 and 2 and indicate the direction and magnitude of the effect of each variable on expert authority. The coefficients are indistinguishable from zero $(p<0.05)$ when the bars cross the zero line.

bureaucracies enjoy among ministry officials from these countries. These results are robust to a variety of specification choices (see below).

However, we can reject the hypothesis that the perceived impartiality of international bureaucracies' work enhances their expert authority. The coefficients for IMPARTIALITY are negative 
in both models, which already contradicts our expectation of a positive relationship with EXPERT AUTHORITY. Moreover, the correlation is small and statistically insignificant. Hence, impartiality is not associated with expert authority. This does not only contradict our expectations but also challenges a prominent assumption in the literature on the relationship between expert authority and impartiality. ${ }^{112}$ What could explain our finding of almost no correlation between impartiality and expert authority? A methodological explanation might be that IMPACT absorbs the effects of IMPARTIALITY, since the latter might contribute to an international bureaucracy's perceived impact. To account for this possibility, we estimated the model excluding each of the two variables. In both variants, the results remain robust and IMPARTIALITY continues to have no statistically significant effect. A theoretical explanation might be that impartiality only matters for de facto expert authority under certain circumstances. In this case, impartiality would have no significant effect on expert authority in the overall sample. For example, it is conceivable that ministry officials care less about impartiality when the international bureaucracy's advice is congruent with national policy preferences, and that they happily recognise the expert authority and defer to it. ${ }^{113}$ In the reverse case, that is, when the advice is not congruent, or is less congruent with national policy preferences, impartiality may be more important for expert authority. Here, ministry officials might have to justify why they intend to follow advice that runs counter to or does not fit their national policy preferences and to do so, they might look at the impartiality of a bureaucracy's work. However, as we elaborate below, our additional analyses reveal that impartiality is never correlated with expert authority, irrespective of the degree of policy congruence.

The regression results in Model 2 also show that the coefficients of the two control variables PRESSURE and CONGRUENCE are positive and statistically significant at the 5 per cent level. The coefficient of the variable CONGRUENCE is even the second largest in Model 2. Furthermore, the coefficient of the variable COERCION is also statistically significant but only at the 10 per cent level and the size of the coefficient is comparatively small.

At first sight, and given the lack of theoretical arguments in the literature that coercion and congruence cause expert authority, these observations only confirm our expectation that the expert authority of international bureaucracies might empirically coincide with other means that they rely on to have their voice heard. In other words, it occurs quite often that ministry officials perceive an international bureaucracy to be an expert authority, and therefore, consider its policy advice, while they also find its advice to be highly congruent with the policy preferences in their country, perceive the respective IO to have coercive potential, or feel pressured by other actors to follow its advice. To be sure that de facto authority occurs in the absence of other forms of power and other motives for the consideration of policy advice, we performed several additional tests. First, descriptive statistics show that higher levels of expert authority are even attributed to international bureaucracies when they belong to IOs that are perceived to have low coercive potential (see Figure 5 below. For the respective figures for the degrees of expert authority conditional on PRESSURE and CONGRUENCE, see Appendix G in the supplementary material).

To assess in greater detail whether our explanations for EXPERT AUTHORITY change when other motives to consider international bureaucracies' policy advice are present or not (and given that the regression results in Models 1 and 2 slightly differ), we decided to create respective subsamples and contrast the two extremes of each of these control variables (lower versus higher values). ${ }^{114}$

\footnotetext{
${ }^{112}$ See, for example, Barnett and Finnemore, Rules for the World; see also the recent review by de Wit et al., 'International bureaucracy', p. 65.

${ }^{113}$ For the argument on sympathetic interlocutors, see Ngaire Woods, The Globalizers: The IMF, the World Bank, and their Borrowers (Ithaca, NY: Cornell University Press, 2006).

${ }^{114}$ Likewise, it would have been possible to estimate a regression model using interaction effects. However, given the lack of concrete assumptions about possible interactions, we would have to include an interaction term for each independent variable and each control variable, leading to a total of 12 interaction terms. This would be more difficult to interpret and display graphically.
} 


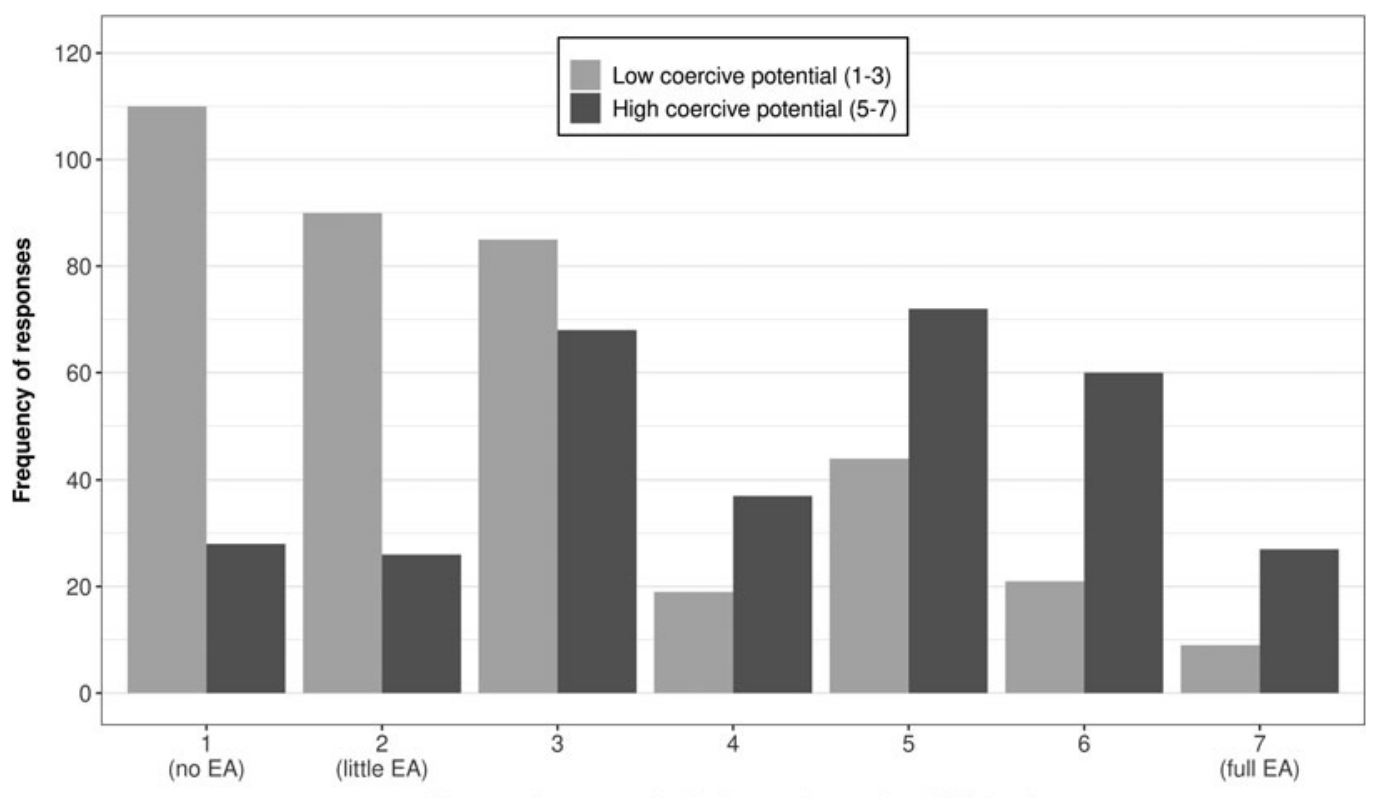

Degree of expert authority from 1 (lowest) to 7 (highest)

Figure 5. Comparison of the frequency of responses for different degrees of expert authority conditional on the perceived coercive potential (IOs with low versus IOs with high perceived coercive potential).

Models 3 and 4 distinguish IOs with lower coercive potential from IOs with higher coercive potential (as perceived by the policy units in national ministries). Models 5 and 6 differentiate between international bureaucracies whose advice is perceived to be rather incongruent with national preferences and those whose advice is perceived to be rather congruent. Models 7 and 8 separate the sample according to whether policy units in national ministries felt pressured to a high or to a low extent by other actors to act on an international bureaucracy's advice. Table 2 presents the results of these estimations.

Most importantly and remarkably, the results on our variables IMPARTIALITY and IMPACT remain robust. ${ }^{115}$ In all models, we find again that IMPARTIALITY is consistently negatively correlated with EXPERT AUTHORITY and that the coefficients are relatively small and statistically insignificant. Regarding IMPACT, we observe that it is consistently positively correlated with EXPERT AUTHORITY, that its coefficients are the largest in size and are all statistically significant. In Models 4, 6, and 8, IMPACT is the only variable that is statistically significant. This increases confidence in the findings from Models 1 and 2, namely that IMPACT is associated with de facto EXPERT AUTHORITY, while IMPARTIALITY is not.

In contrast, the results for OBJECTIVITY and ASYMMETRY differ among the subsamples. In this regard, Models 3-8 allow us to specify the relationship between OBJECTIVITY and EXPERT AUTHORITY, on the one hand, and ASYMMETRY and EXPERT AUTHORITY, on the other. Both only correlate with de facto expert authority when the IOs to which international bureaucracies belong are perceived to have a rather low coercive potential (Model 3), when the international bureaucracies' advice is perceived to be congruent with national preferences (Model 6), or when the policy units of ministries do not feel (strongly) pressured by other actors to act on the advice of an international bureaucracy (Model 7). In the three other subsamples, the correlations are statistically insignificant.

\footnotetext{
${ }^{115}$ Overall, the key results are not substantially affected when dividing the sample into subsamples, given that the directions of the marginal effects only change in Model 8 for ASYMMETRY.
} 
Table 2. Results of Models 3 to 8 (subsamples).

\begin{tabular}{|c|c|c|c|c|c|c|}
\hline & \multicolumn{2}{|c|}{ COERCION } & \multicolumn{2}{|c|}{ CONGRUENCE } & \multicolumn{2}{|c|}{ PRESSURE } \\
\hline & $\begin{array}{l}\text { Low } \\
\text { (3) }\end{array}$ & $\begin{array}{l}\text { High } \\
\text { (4) }\end{array}$ & $\begin{array}{l}\text { Low } \\
\text { (5) }\end{array}$ & $\begin{array}{l}\text { High } \\
(6)\end{array}$ & $\begin{array}{l}\text { Low } \\
(7)\end{array}$ & $\begin{array}{l}\text { High } \\
(8)\end{array}$ \\
\hline IMPARTIALITY & $\begin{array}{l}-0.034 \\
(0.088)\end{array}$ & $\begin{array}{l}-0.080 \\
(0.111)\end{array}$ & $\begin{array}{l}-0.060 \\
(0.127)\end{array}$ & $\begin{array}{l}-0.039 \\
(0.076)\end{array}$ & $\begin{array}{l}-0.028 \\
(0.063)\end{array}$ & $\begin{array}{l}-0.011 \\
(0.140)\end{array}$ \\
\hline OBJECTIVITY & $\begin{array}{l}0.247^{\star \star} \\
(0.091)\end{array}$ & $\begin{array}{l}0.082 \\
(0.105)\end{array}$ & $\begin{array}{l}0.046 \\
(0.159)\end{array}$ & $\begin{array}{l}0.132^{\prime} \\
(0.071)\end{array}$ & $\begin{array}{l}0.145^{\star} \\
(0.065)\end{array}$ & $\begin{array}{l}0.057 \\
(0.120)\end{array}$ \\
\hline IMPACT & $\begin{array}{l}0.457^{\star \star \star} \\
(0.097)\end{array}$ & $\begin{array}{l}0.589^{\star \star \star} \\
(0.079)\end{array}$ & $\begin{array}{l}0.321^{\star \star} \\
(0.119)\end{array}$ & $\begin{array}{l}0.619^{\star \star \star *} \\
(0.070)\end{array}$ & $\begin{array}{l}0.442^{\star \star \star} \\
(0.059)\end{array}$ & $\begin{array}{l}0.735^{\star \star \star} \\
(0.129)\end{array}$ \\
\hline ASYMMETRY & $\begin{array}{l}0.167^{\star} \\
(0.073)\end{array}$ & $\begin{array}{l}0.049 \\
(0.124)\end{array}$ & $\begin{array}{l}0.112 \\
(0.162)\end{array}$ & $\begin{array}{l}0.187^{\star \star} \\
(0.061)\end{array}$ & $\begin{array}{l}0.189^{\star \star \star} \\
(0.056)\end{array}$ & $\begin{array}{l}-0.008 \\
(0.154)\end{array}$ \\
\hline Intercept & $\begin{array}{l}0.310 \\
(0.233)\end{array}$ & $\begin{array}{l}0.358 \\
(0.455)\end{array}$ & $\begin{array}{l}0.288 \\
(0.310)\end{array}$ & $\begin{array}{l}0.359^{\star} \\
(0.166)\end{array}$ & $\begin{array}{l}0.318 \\
(0.167)\end{array}$ & $\begin{array}{l}0.613^{*} \\
(0.285)\end{array}$ \\
\hline $\mathrm{R}^{2}$ & 0.443 & 0.346 & 0.623 & 0.403 & 0.456 & 0.597 \\
\hline Adj. $R^{2}$ & 0.348 & 0.236 & 0.313 & 0.343 & 0.407 & 0.416 \\
\hline Num. obs. & 303 & 278 & 94 & 485 & 526 & 130 \\
\hline
\end{tabular}

Notes: OLS regressions with two-tailed significance for estimates. $p<0.1 ;{ }^{*} p<0.05 ;{ }^{* \star} p<0.01 ;{ }^{\star \star *} p<0.001$. Standardised coefficients with robust standard errors clustered by respondent (in parentheses). Fixed effects for the international bureaucracies in their thematic areas are omitted from the table.

\section{Robustness of the results}

This article conducted theory-guided tests by means of regression analyses. We used a range of control variables to filter out the effect of potential confounders, and we performed a series of robustness checks in order to increase the validity of our results (see Appendix $\mathrm{H}$ in the supplementary material). Robustness tests included an ordered logistic regression for Models 1 and 2 that confirms the results from the OLS regression. Given the (slightly) diverging response rates in the different regions and thematic areas, we used non-response-adjusted survey weights. This did not change key estimates; only some of the coefficient values changed and by not more than 0.1. We also estimated our models with standard errors clustered at the country level instead of the respondent level, and we included further control variables at the country level in our models. The results remained similar. Finally, we calculated the variance inflation factor (VIF) to rule out multicollinearity. For each of our explanatory variables, the VIF is less than 2. Consequently, multicollinearity is unlikely to influence our results in a substantive way.

\section{Conclusion}

Using novel survey data, this article showed that international bureaucracies enjoy varying degrees of de facto expert authority among policy units in ministries. The analysis sought to explain this variation and evaluate the explanatory power of established assumptions. While IO scholars have for long claimed to know why international bureaucracies enjoy expert authority, we found substantial empirical support for some but not other arguments. First, our core finding is that international bureaucracies enjoy expert authority among policy units in national ministries mainly when they are perceived to effectively address global challenges, to which we referred as perceived impact. This finding was robust to various alternative specifications. It holds independent of existing peerpressure on states, in the absence and presence of coercive potential, and irrespective of whether international bureaucracies provide advice that is in line with national preferences. Second, we found no empirical evidence that perceptions of international bureaucracies' impartiality affect their de facto expert authority. This is not to say that impartiality is irrelevant for international bureaucracies, per se. It appears plausible that impartiality matters much more when it comes to authority relations with other audiences, such as societal actors. For the literature on (international bureaucracies') expert authority, this is a surprising finding. Typically, scholars assume that 
subordinates do not defer to sources they regard as partisan. Third, the findings for both objectivity and knowledge asymmetry depend on the composition of the sample, for instance, the presence or absence of peer pressure. Both correlate with de facto expert authority only when the IO to which the international bureaucracy belongs has low coercive potential, when peer pressure is perceived to be low, or when the international bureaucracy's advice is perceived to be in line with national domestic preferences. The opposite constellation is a likely candidate for politicisation. Thus, whereas the previous literature has regarded objectivity as a shield against politicisation and hence an important source of international bureaucracies' authority, our research leads us to the proposition that objectivity might not be enough of a shield for coercive IOs. These still may enjoy expert authority but need to have a reputation of being impactful.

Our analysis refers to a specific group of subordinate actors: national ministries. We do not know whether expert authority follows similar patterns with other relevant stakeholders such as citizens or politicians. However, considering the importance of national administrations as gatekeepers and domestic intermediaries for international bureaucracies' policy advice, our findings are particularly relevant for debates on the national influence of IOs.

Despite the focus on one stakeholder group, the implications our research implies for IOs that seek to preserve their expert authority, in times of contested multilateralism, ${ }^{116}$ are clear. If international bureaucracies want ministerial units to follow their advice, they should emphasise their record as effectively addressing global challenges, as this is the only aspect that holds for all international bureaucracies, irrespective of other circumstances. It is also the only aspect that is important when international bureaucracies are at risk of being politicised, that is, when they belong to IOs with high coercive potential, when they provide advice that tends to be less congruent with national policy preferences, and when third-party actors exert pressure to act on their advice. Second, those international bureaucracies that cannot rely on other means of inducing deference should ensure that they are able to present their work as objective. By doing so, they can preserve the heart of their bureaucratic power.

Acknowledgements. We thank the RIS editors, three anonymous reviewers, Martin Binder, Thomas Diez, Thomas Dörfler, Matthias Ecker-Ehrhardt, Steffen Eckhard, Mirko Heinzel, Anja Jetschke, Pekka Kettunen, Martin Koch, Julia Leib, Nina Reiners, Henning Schmidtke, Duncan Snidal, Matthew Stephens, and Alexandros Tokhi for their helpful comments. Earlier versions of this article were presented at the ECPR General Conference in 2016 and 2017, the ISA Annual Convention in 2017, and the EISA Pan-European Conference on International Relations in 2017, and we are grateful to participants for their comments. We also thank our survey respondents. Finally, we thank Benedict Bueb, Mamy Dioubaté, Serene Hanania, Luise Köcher, Sascha Riaz, Dunja Said, and Antje Specht for research assistance and support in conducting the survey.

The opinions in this article are those of the authors and do not necessarily reflect the views of the Deutsche Bundesbank, the Eurosystem, or any other institution with which any of the authors are currently affiliated. All remaining errors are our own.

Funding by the German Research Foundation (DFG) as part of the Research Unit FOR\#1745 'International Public Administration (IPA)' with Grant No. LI 1947/1-1 is gratefully acknowledged.

Supplementary material. To view the online supplementary material, please visit: https://doi.org/10.1017/S026021052100005X

Andrea Liese is Professor of International Relations at the University of Potsdam. Her research interests include international organisations and their bureaucracies, the authority of experts, dynamics of international norms, and the governance of (sustainable) development and human rights. Her previous work has appeared in journals such as Global Constitutionalism; Governance; and the Review of International Political Economy. Author's email: aliese@uni-potsdam.de

Jana Herold is an Associate Professional Officer at the Food and Agriculture Organization of the United Nations (FAO). From 2014-20 she was a Research Associate at the University of Potsdam, where she also gained her doctorate. Her research interests include international organisations and development cooperation. Author's email: jana.herold@uni-potsdam.de

Hauke Feil is a statistician at the Deutsche Bundesbank. From 2014-18 he was a Research Associate at the University of Potsdam where he also gained his doctorate. His main fields of research are international organisations, survey methods, and development cooperation. Author's email: hauke.feil@bundesbank.de

\footnotetext{
${ }^{116}$ Julia C. Morse and Robert O. Keohane, 'Contested multilateralism', Review of International Organizations, 9:4 (2014), pp. $385-412$.
} 
Per-Olof Busch is a Senior Project Manager at adelphi, a leading independent think tank on climate, environment, and development. From 2010-20 he was a postdoctoral researcher at the University of Potsdam, where he worked on international organisations, environmental and sustainability governance, and policy diffusion and transfer. Author's email: busch@adelphi.de

Cite this article: Liese, A., Herold, J., Feil, H., Busch, P.-O. 2021. The heart of bureaucratic power: Explaining international bureaucracies' expert authority. Review of International Studies 47, 353-376. https://doi.org/10.1017/S026021052100005X 